\title{
From the Periphery to the Center: Young People's Agonistic Pathways Towards Higher Education
}

\author{
Felipe Salvador Grisolia and Lucia Rabello de Castro
}

\begin{abstract}
The present research analyzes the mobilities of young people from the periphery of Rio de Janeiro towards a renowned university situated in a central region of the city. Focusing on a case study with four students, we carried out an in-depth investigation of the dynamics of their professional trajectories. Their personal identifications and values, their future career expectations and the pressures and the demands of attending such a university were investigated. Three focus groups meetings were organized with these students. The results show that the displacement from home to the university, social and racial segregation, and arduous academic demands are factors that pose enormous difficulties to these students and require intense psychological work on their part to persist in their educational investment. Intense conflicts with regards to living up to their ideals characterize an agonistic pathway in their educational endeavor. On the other hand, the prestige of the university, family influence and the belief in upward social mobility were found to support these young people's decision not to give up. This contradictory dynamic, riddled with uncertainties, mobilizes these young people to find a way to permanently renovate their personal stakes in higher education.
\end{abstract}

Keywords: peripheral youth, university, mobility, professional expectations

Felipe Salvador Grisolia has a PhD in Psychology from the Federal University of Rio de Janeiro. He is an Assistant Professor in the Education Department at the Federal University of Rio de Janeiro. Research interests include youth in education and in labour. Major publications include: Castro, L. \& Grisiolia, F. (2016). Public subjectivization or political socialization? Articulating the political and childhood. Educação e Sociedade, 37 (137), 971-988; and Grisolia, F. \& Castro, L. (2016). The standardization of fast-food and its effects in the subjectivity of the young worker". Gerais, 9 (2), 211-226.

Lucia Rabello de Castro has a Ph. D. in Psychology (University of London, UK). She is a Full Professor at the Federal University of Rio de Janeiro, Institute of Psychology. Research interests include political and social participation of children and youngsters. Major publications include: Savegnago, S. \& Castro, L. (2020). Opportunités et mobilités de jeunes des classes populaires de Rio de Janeiro, Brésil. Revue Jeunes et Société, 5, 99-124; Castro, L. (2019). Why global? Children and childhood from a decolonial perspective. Childhood, 27(1), 48-62; and Castro, L. \& Baraldi, C. (Eds.) (2020). Global Childhoods in International Perspective: Universality, Diversity and Inequalities. London: SAGE. 


\section{Introduction}

In this study, we analyzed how young people from the peripheral areas of the city of Rio de Janeiro construct their career and educational expectations as they attempt an educational movement towards a prestigious university. Universities in Brazil have been historically attended by young people from the middle and upper classes (Mayorga, Costa \& Cardoso, 2010). However, recent public policies have expanded student enrollment vacancies in higher education, thus contributing for tertiary education to emerge in the horizon of lower income young people's possibilities, often coming from urban peripheries. These new educational mobilities take place within a contradictory dynamic, as they combine the impoverished and peripheral settings from where the young people originate and the valued well-off spaces which they now attend. These mobilities seem to entail gridlocks, difficulties, and challenges as young people attempt to build a new professional path different from their family's social condition as some previous research in Brazil has already indicated (Almeida, 2007; Mongim, 2015; Piotto, 2010; Zago, 2006).

This article is structured as follows: firstly, we discuss how an uneven socio-spatial structuring of opportunities entails a gamut of different courses of educational and professional action for young people living in different regions. We then briefly describe the Brazilian university system to understand the pathways of peripheral young people in these institutions. Subsequently, we detail the methodology used in our research and discuss how young people justify and subjectively experience enrollment in a renowned higher education institution and their resulting expectations. Our analysis focuses both on what the internal psychological labour carried out by young people to meet the demands imposed by the university consists of and what are the relevant aspects that contribute to sustain this movement towards a renowned educational institution.

\section{Locality as a Determinant of Inequality in Structuring the Lives of Young People}

Space and place have been underexplored dimensions when it comes to the study of youth. International (Cuervo \& Wyn, 2017; Farrugia, 2014; Farrugia \& Wood, 2017; Geldens \& Bourke, 2008) as well as Brazilian studies (Mayorga \& Pinto, 2013) point out that a significant part of the research on youth has focused on the urban middle classes, as if this were their natural context. This has led to the invisibilization of youth of other contexts, such as those of rural environments (Weisheimer, 2013) leading to negative consequences, such as, lesser public policies for this segment.

Farrugia (2014) has argued that the scarce attention to the spatial issue in youth studies derives from its broader absence in social studies which tend to think of the city as the natural human habitat. Furthermore, the author argues that sociological theories very much in vogue in debates about youth, such as Giddens' reflexive modernity and Beck's individualization theory, are often employed to legitimize the exclusion of space and locality. This so happens because such theories emphasize, on the one hand, the demise of major traditional social markers which once informed the individual and his/her actions in the world, and on the other hand, the increased emergence of the reflexive individual who takes him/herself as the measure of one's own actions. As Farrugia shows (2014), stemming from this diagnosis and grounded on a superficial reading of Giddens and Beck, many studies have argued that structural factors such as class, race, gender, and place of residence have lost much of their importance in view of the reflexivity of the social actor. Thus, location has been ultimately relegated to a secondary status in view of the reflexive processes of the contemporary individual. 
Against this demotion of the spatial dimension, Gyerin (2000) argues that location cannot be reduced to a mere background, an indifferent context where certain events take place and where the individual may freely act reflexively. Rather, locality is a structuring factor in the very production of these events and in making possible the subject's action. The author argues that, for example, democratic elections, the jurisdiction of certain laws, or a conversation are all located social situations and, as such, structured to a greater or lesser extent by the place in which they exist. Likewise, the production of the youthful subject is also always localized (Farrugia, 2014) and several studies have addressed the issue of how place produces ways and conditions of subjectivization for young people (Castro, 2013; Cordeiro \& Menezes, 2001; Farrugia, 2014; Geldens \& Bourke, 2008; Perez \& Castro, 2011; Savegnago, 2018), and how it may or may not foster a sense of belonging (Cuervo \& Wyn, 2017; Stahl \& Habib, 2017; Stahl \& Baars, 2015) in them.

Therefore, the locality of the social actor is not a mere indifferent background, but rather responsible for structuring, to a greater or lesser extent, the possibilities of action and production of this subject. In this direction, Farrugia (2014) argues that locality is a factor that entails unequal experiences for young people, as different locations provide different possibilities and courses of action. We can see this dynamic in Jensen's study (2006) in which the author surveyed middle-class urban youths in Copenhagen to show how these young people understood mobility as a right that they exercised when moving around the city. Jensen (2006) goes as far as to state that mobility is an attribute of the contemporary youth. In his words:

Young people, particularly, are part and parcel of the 'mobility development', as they have grown up with television, computers, emails, Internet, mobile phones and so on, as well as cars, bikes, buses, trains and aeroplanes: all technologies that make the young generation mobile as never before, and which they take for granted and consider a right that cannot be questioned. (...) To young people of today, mobility and modernity are two sides of the same coin, where mobility is an essential prerequisite of modern life. (p. 345).

However, the possibility and desire for mobility are not equally distributed across the globe. In a study with young people from Rio de Janeiro, Pérez and Castro (2011) addressed how both more affluent as well as low-income youth are restricted in their transits. Young people from these two socioeconomic backgrounds mentioned that they preferred to stay close to their residence for safety reasons. In another study carried out in the city of Rio de Janeiro, Cassab (2001) underscored the constraints faced by poor black youth when moving around the city, as they resented the constant inquiries, such as stop and frisk practices imposed by police officers. We note how the prevailing structural racism in the country, internalized by security agents, imposes constraints on the free movement of young Black bodies, not seldom seen as threats to the prevailing social order. A different type of confinement emerges in the work of Cuervo and Wyn (2017) with young Australians from a rural community, in which one of the interviewed young women expressed how she felt trapped in her locality, forced to remain at home caring for her sick grandfather. All these studies ultimately emphasize that mobility is not evenly distributed among young people. Thus, the notion that displacement is taken for granted as a right by today's youth, as argued by Jensen (2006), may be disputed.

Not only does the possibility of mobility vary according to location, the same holds true for educational opportunities and professional expectations. The aforementioned work by Cuervo and Wyn (2017) in rural Australia shows how individuals who wished to enroll in higher education had 
to acquire resources to move to other locations in which this infrastructure existed. Similarly, Lebourg and Coutrim (2018) performed a study with young people from a small rural municipality in Brazil, where students must travel circa $20 \mathrm{~km}$ to attend high school, the last stage of compulsory basic education according to the Brazilian legislation. ${ }^{1}$ In their study, while the young people's testimonies point out that this movement may be attractive insofar as youth get in touch with other spaces and people, other students saw this in a negative light, as displacement demanded time and energy and the unknown was often felt as a source of discomfort and fear.

Some studies have also emphasized the importance of locality for structuring expectations and professional paths. Schlemmer (2005) analyzed how local conditions in Fez, Morocco, impel children and young people towards craftwork. This type of activity is widespread in the region and master craftsmen deem highly schooled children and young people to be less disciplined, and thus have no interest in hiring them. Hence, many children and young people end up gravitating towards craftwork rather than school. As for the European context, Fraser et al. (2017) focused on how changes in Glasgow's occupational structure, resulting from the city's deindustrialization, have transformed the local labour market and, consequently, the labour possibilities and expectations of their youth. Thus, contemporary young Glasgowians tend to enter the labour market at an older age and take up jobs in the tourism and service sector, which grant them lower wages and labour guarantees compared to their counterparts in the 1960s. In a similar context of declining industrial employment and the emergence of the service sector, Stahl and Baars (2015) analyzed the professional expectations of young urban men in working-class neighborhoods in England. The authors question the prevailing common-sense idea, equally found in the discourse of British politicians, that young people in these neighborhoods have limited aspirations. Instead, the researchers found that many young people plan to continue their studies, but such planning is closely dependent on their school performance in exams and the possibility of moving to places with tertiary education institutions. If school performance is insufficient, or displacement is not possible, young people aspire to enter the labour market, usually in the trade sector, and hope to find jobs where they can earn enough to provide for their future families.

In the state of Rio de Janeiro, Peregrino and Fernandez (2014) addressed how young people living in different regions of São Gonçalo, a city within the state metropolitan region, tend to have different educational paths and professional hopes. As the authors argue, young people living in places with a greater supply of public facilities are more likely to attend a higher quality school and devise a professional project when compared to young people living in the periphery, as the latter tend to study in lower-quality schools and find it more difficult to envisage a professional project for themselves. Similarly, Savegnago (2018) argues that perhaps the focus should be less on the expectations and future professional projects when it comes to poor and peripheral young people in Rio de Janeiro, but rather the availability of educational or employment opportunities. Savegnago (2018) outlined how the young people she researched found it difficult to think about and plan a distant future, living their lives in a more immediate day-to-day dimension, trying to remain alert to opportunities and possible gains that the present may offer. While this focus on the present may acquire particular undertones for young people living in the periphery of Rio de Janeiro, it is also characteristic of the contemporary world insofar as fast changing demands in an automated and technological labour market make long-term thinking and planning a difficult, if not an impossible, task. (Bauman, 2008; Beck \& Beck-Gersheim, 2002; Boltanski \& Chiapello, 2007; Dardot \& Laval, 2016; Sennette, 2009). Thus, we find that different opportunities regarding mobility, study, and work are unevenly distributed across the social space. In the following section, we provide a brief contextual panorama of higher education in Brazil, as recent public policies have made tertiary education more accessible to young people from low-income backgrounds and peripheral contexts, creating conditions for university enrollment to emerge in their foreseeable horizon.

\footnotetext{
1 Brazilian basic education comprises the following segments: early childhood education (ideally between 0 and 5 years old), elementary education (ideally between 6 and 14 years old), and high school (ideally between 15 and 17 years old).
} 


\section{Higher Education: A New Horizon for the Poor Youth of the Peripheries?}

As shown by several national studies (Mayorga, Costa \& Cardoso, 2010; Neves \& Martins, 2016; Vasconcelos, 2016), a large number of the country's higher education students has historically belonged to the middle and upper classes. However, different social and political movements in Brazilian society have pressed to make this institution more democratic (Mayorga, Costa-Moura \& Savegnago, 2019), resulting in federal and state policies for the expansion and the geographic spread of federal universities ${ }^{2}$, the creation of social quotas by reserving some of the vacancies in public universities for low-income people, Black people, and Indigenous people, and the creation or reformulation of sponsorship programs for scholarships in private universities, all of which have contributed to a higher participation of peripheral young people in universities (Mayorga, CostaMoura \& Savegnago, 2019). Corbucci (2016) revealed that from 2000 to 2010, there was a relative percentage increase of young people with an average income of up to 1.5 minimum wages enrolling in higher education compared to other socioeconomic groups of youth. While in 2000 this population accounted for $4.7 \%$ of the net enrollment rate at this educational level, in 2010 it increased to $26.5 \%$. Most recent data show even more positive rates when we look at the inclusion of the low-income population in federal universities, as most students in these universities (50.9\%) come from families with a per capita income of up to 3 minimum wages (Andifes, 2018) which represents a major shift in the population attending federal universities, an effect of the public policies aforementioned (Mayorga, Costa-Moura \& Savegnago, 2019).

However, the Brazilian expansion model for higher education has been criticized due to the high reliance on the private sector, which accounts for up to $70 \%$ of enrollments (Vasconcelos, 2016). This is a problematic situation as public institutions are renowned for their better quality and their threefold focus on teaching, research, and outreach which are not necessarily available in private universities (Neves \& Martins, 2016; Vasconcelos, 2016). Therefore, the Brazilian expansion model has accorded priority to private universities, which tend to provide a lower quality education when compared to public universities.

Notwithstanding this caveat, it seems that higher education has become a potential stage of educational formation and professional training for several young men and women among poor and peripheral young Brazilians who have increasingly enrolled at this educational level, thus creating conditions for still further expansion. As Bourdieu (1998) argued, the expectations that social actors have about the educational system are directly related to the possibilities of success within that system. Likewise, the French sociologist reminds us that the school system is closely linked to the occupational system insofar as the attainment of certain diplomas becomes crucial to access certain work positions (Bourdieu \& Boltanski, 1998). Thus, as more higher education vacancies become available and more young people from the peripheries enroll, the occupational horizon of this population tends to broaden.

Next, we present the methodology of the present research. We provide a discussion and case analysis of a group of four university students of the periphery of Rio de Janeiro and their mobilizations towards a prestigious university institution in a central area of the city. We scrutinize the subjectively experienced contradictions and conflicts that emerge as these young students enroll in this educational institution, and how their expectations develop towards their future professional life as they participate in this institution.

\footnotetext{
${ }^{2}$ Federal universities are managed by the Brazilian federal government. Public universities also include state universities and, more rarely, municipal universities.
} 


\section{Methodology}

We conducted a case study with four university students - three young people and one adult - enrolled in the same institution and whose social origin was from the peripheral regions of the city of Rio de Janeiro. The participants were recruited at random for this study, with the assistance of the university staff where the research took place. An invitation email was sent out with a brief explanation about the research to their fellowship students belonging to the federal program Programa Universidade para Todos - ProUni (University for All Program - ProUni) ${ }^{3}$. Those students who, of their own free will, decided to share their educational trajectory, university experience, and expectations of the future with the main researcher were included. Many students that showed interest to take part in the research could not be included on account of their very tight study and work daily schedule.

While cognizant of the limitations of our qualitative methodology in terms of broad generalizations, our intent was to perform a detailed and thorough analysis of the participants' educational trajectories and life-histories, their university experiences and professional expectations. We discussed how their social relationships with parents, teachers and friends enabled a complex network of identifications that became key aspects as they decided to pursue higher education in a prestigious institution. Through our findings we were able to acknowledge the challenges, difficulties and hopes faced by these young people from the peripheral areas of Rio de Janeiro in their strive towards a university degree. Table 1 lays out a brief profile of the subjects who participated.

Table 1:

Profile of the Surveyed University Students

\begin{tabular}{|l|l|l|l|l|}
\hline Name $^{4}$ & Age & Gender & Place of Origin & University Course \\
\hline A. & 26 & Male & Madureira & Business \\
\hline Ad. & 48 & Male & Fallet & Geography \\
\hline R. & 22 & Female & São Gonçalo & Business \\
\hline W. & 20 & Male & Campo Grande & Psychology \\
\hline
\end{tabular}

\footnotetext{
3 ProUni refers to "Ministry of Education program that grants full and partial scholarships in private universities, degree and specific qualification courses, for Brazilian undergraduate students". http://siteprouni.mec.gov.br/ Accessed in 09/24/2019.

${ }^{4}$ To ensure the confidentiality of the participants, their original names were replaced by their initials.

5 The term place of origin is used instead of place of residence since some young people move to areas closer to the university. One exception is Ad., who reported moving with mothers and siblings from another region of Brazil, the Northeast, in search of better life conditions. Madureira and Campo Grande are neighborhoods located in the North and West Zones of Rio de Janeiro. São Gonçalo is a municipality in the Metropolitan Region of Rio de Janeiro. Fallet is a favela located in downtown Rio de Janeiro.
} 
We listened to the participants' life trajectories over the course of three group meetings, lasting between 40 and 60 minutes each. The first two meetings were focused on discussing the experiences, expectations, anxieties and difficulties faced by these young people in basic schooling and also in the university. In the third meeting, we discussed the expectations and pressures as they thought about and devised a professional future. We sought to address the past, present and future of these young people, what prompted them to enroll in a university, how they evaluated their situation in it, and what they expected from their future. Through their testimonies, we compiled evidence to shed light on how these young people sustained the displacement from the periphery to the center, even if bearing heavy difficulties and uncertainties. We also analyzed how this displacement entailed expectations and frustrations that young people had to constantly face in their educational choices and professional expectations.

\section{Discussion and Analysis of the Results}

The participants' testimonies revealed that the movement from the periphery to the center is riddled with difficulties. The physical displacement towards the university, the first-time experience with higher education studies, and even the social distance between scholarship and non-scholarship students were some of the adversities mentioned by the young people when attending an educational institution whose history has targeted the middle and upper class students. Even amid such adversities, they justified their displacement from the periphery to the center insofar as they were moving towards a socially renowned institution which according to their perspective - their own as well as their families' - would allow them to achieve better life conditions. Below we discuss the contradictions that befall such a movement from the periphery to the center, and subsequently, we focus on how these young people cope with these difficulties and find the means to pursue and sustain an investment stake on higher education amid these hardships.

\section{Displacement, Segregation and Academic Lack: Conflicts and Contradictions in the Pathway of the Periphery to the Center}

The first hurdle that young people face concerns the physical movement from the periphery, their place of origin, towards the center where the university is located. The young people expressed that getting to college is a challenge, a chore, a daily difficulty, as typified by W's account:

At first, transportation was very difficult, because I lived in Campo Grande. So, that's almost a 3-hour trip (...) And that was really exhausting for me, in fact I was studying hard and I couldn't handle it anymore. There reached a point when I arrived home crying and said 'Man, I don't want college anymore. I don't want to study anymore. I don't know, I don't see the point in this, of destroying myself, like busting my ass to get to college and then busting my ass in college just to stay in college'. 
This, as well as other accounts, revealed that the physical displacement to college was cumbersome and demanded not only time, but subjective labour from the subjects to persist in their chosen educational project, as they became increasingly tired and exhausted along the way. Physical and psychological pressure, as expressed by $\mathrm{W}$, often led to questioning their educational project itself urging them to find new reasons and motivations to persist in their projects.

Such an experience of the young people from the periphery lies in contrast with the experience of students living in central regions. Those who live in high-valued locations close to the university do not waste so much time with commutes, and can dedicate themselves to the various required tasks and events offered by the university environment, in addition to having more free time to devote themselves to varied activities. To mitigate this problem, W reported that he got a job so that he could move close to the university. Thus, this young man decided to work to be able to share the cost of a house rent with other young roommates. A similar expedient was reported by $\mathrm{R}$. The latter, a young woman, said she was staying as a guest with a relative, in a place close to college, which saved her money on transportation and time on her daily commute. Hence, the distance from the periphery to the center hinders the mobility of individuals coming from peripheral regions and becomes a hardship to be coped with. These difficulties must be endured on a daily basis or remedied by other means, such as family connections or entry into the labour market as reported by some of the respondents in our study.

Another difficulty which posed enormous subjective demands and internal readjustments from peripheral youngsters emerged in their encounter with higher education. The individuals in our research reported a striking difference between the educational requirements in the high schools they attended, of low quality, and the requirements imposed by the renowned university. A's account exemplifies this issue:

...I came from a state school, which is fine, but I didn't have a solid math education back then. So when I got here I fell flat on my face and flunked. That was my only F grade. (...) I've always struggled a lot with math, and I didn't have a math teacher; as I remember, in my second year of high school I didn't have one. Throughout the whole year we were 5 months without a math teacher. So, when I got here, I saw the other students and the teacher say 'Ok! Solve this equation, solve this here' and so on.' And I looked at that and I said 'man, I can't do that. I don't know any of this.' I'd look at the blackboard, I'd look at the textbook 'I don't know how to this! I don't know!'

Here a big discrepancy was found between the skills that the young people believe they have and the demands that emerge in a higher education course of a renowned university. It seems that young people from peripheral contexts have not internalized the necessary set of dispositions, i.e., the required habitus (Wacquant, 2007) to handle the tasks of a university institution whose clientele usually comes from the middle and upper classes. Thus, A felt at a loss as to how to behave as he found out suddenly his 'lack of knowledge', one that he should have acquired during his high school period but he did not, as in a state school destined for the low-income strata teachers were often missing. This experience is reported to generate confusion and disorientation in youth, in them not knowing what to do. This was a feeling that was expressed by all the young people in our study as they evaluated their educational trajectory and what was demanded at university. This dynamic exposes what Kuenzer (2010) defined as the duality of the Brazilian school system, in which a double system exists with good schools for the economic elites and lower quality schools for the low-income population. 
The young people here had a lower quality educational background, which did not prepare them for the demands of a higher quality educational institution. Therefore, mobility from the periphery to the center tends to position the peripheral individual in a place of lack - not to possess the required dispositions and abilities of how to behave or how to respond to the institutional demands. Faced with their lack of understanding, these young people showed, however, a commitment to continue their studies as they strove to build the necessary capacities to cope with the new academic demands. Thus, A reports that he spent his holidays devoting himself to math studies, with the remedial help of a staff from the university, to overcome his shortcomings in this field of knowledge. This allowed him to pass the exams later on. In failing to build such dispositions, the individual risks seeing him/herself as unable to cope with the demands of their undergraduate course and may abandon it. This is what happened with A, who enrolled in an Engineering undergraduate course, but due to constant failures, changed his course to Geography after some time.

Another difficulty lies in the social relationship of these peripheral young people with other students at the university. The distance from the periphery to the center is not only geographic, but also economic and social, noticeable in how the individuals dress, speak, pick up their tastes and preferences, and adopt consuming styles which bear the mark of different social classes. This difference becomes conspicuous insofar as young people from the center and young people from the periphery tend to group themselves among their own. One example is shown by an account of A:

Yeah, I see some segregation, like between momma's boys and we the scholarship students. And it's funny in a way, incredible really, for example, we'll get together and hang out, right? And when you look at the group, in my case ok, everyone's a scholarship student. Just like that. It's as if we're drawn to each other, something like that. I don't know if it's that obvious, this difference that when we look at someone 'hey, this person is just like me, and so on, I like their values and how they think and all that ', and so we band together.

Similarly, W complained about students from the middle and upper social classes as he believed they disliked the poor and black students and did not want them at the university. Once again, the notion of habitus (Wacquant, 2007) becomes tangible, as in the account by A when he said that banding together with those he sees as his equals is a common, almost natural, experience. The statements by $\mathrm{A}$ and $\mathrm{W}$ show that peripheral students resent being seen as different and feeling left out. Their answer is to give back in the same coin, i.e., to see other students as different and avoid contact with them. The situation reaches a dramatic tone in W's account as he narrated in great detail the alleged intolerance of students from higher economic strata towards the others. This situation, in which difference becomes an insurmountable chasm, seems adverse not only for peripheral students, but for the entire student body. By resorting to this expedient, young people become restricted to the safe ground of similarity and shun away from displacing themselves in the direction of those who are different and the potential subjective gain and growth provided by living with different others. This seems to be a situation that can result in an overall subjective and social impoverishment for students of lower and upper social classes.

The young peripheral student thus faces challenging situations lived as deeply felt hardships as they enter university, a quite unknown universe for them. We think that this situation puts these young men and women in a constant dilemma. They have worked hard to achieve higher education, 
but, as they are faced with the enormous difficulties that their educational choice entails, to give up appear as a way to escape the conflicts posed by the strains of making this unknown universe their own.

These youth had to deal with the physical and psychological exhaustion of making the journey from the periphery to the center; they had to cope with the overwhelming academic demands of a high quality institution as they realized how much they lacked in abilities they should have acquired but had not; they had to face the social and racial segregation and discrimination as they were often viewed as different. Such difficulties were also reported in other researches with young people from low-income classes in Brazil. The young people surveyed by Almeida (2007) also suffered from the great distances they had to travel to the university; those studied by Piotto (2010) mentioned that they did not know how to behave at the university, and those interviewed by Dauster (2003) and Zago (2006) resented the social segregation they suffered.

Dealing with such hardships demanded an intense and constant subjective labour by these young people, as they endured long journeys in public transportation, had to find time and disposition to over dedicate themselves to their studies as a way to meet university requirements, and had to learn how to behave in a social dynamics of negative classification and segregation. Even amid such hardships and difficulties, these young people continued to place their stakes on a higher educational training. Next, we discuss what seems to support this stake.

\section{Hoping for Better Days: The Subjective Stakes of the Peripheral Youth and their Families}

The underlying factors grounding these young people's decision and their subsequent efforts to cross the physical, social, and subjective distance between the periphery and the center are diverse. According to their testimonies, the reasons include the allure of a socially renowned institution, the influence of family members, and the hope for ascendant social mobility. Such factors should not be seen as independent, but closely related. Family influence, for instance - and this has been thoroughly documented in classic studies in the sociology of education scholarship (Lahire, 1997) - emerges as an important aspect of subjective construction within an upward social mobility process grounded on education. This is because the family environment is largely responsible for fostering a habitus inclined towards the appreciation and the dedication to intellectual achievements (Bourdieu, 1998). The family may also foster the belief that a good college degree is tantamount to social mobility, and guide the young person to strive towards these institutions. Therefore, the distinction of these factors is purely analytical, since they often merge and mingle with one another.

Socially valued places exert an appeal over people (Santos, 2000) insofar as such locations concentrate the economic, cultural, social, and political investments of a given region. This appeal may take different forms: in the flow of workers from the most diverse regions of a metropolis towards the city center to work; in global tourism, as major cities become a privileged destination for thousands of people; in the migratory flows of people from one region to another in the hopes of a better life and future.

The university in our research, a prestigious and high quality institution, exerts that appeal over different sectors of society and the young people themselves. The accounts of $\mathrm{A}$ and $\mathrm{Ad}$ exemplify this attraction:

A: I had my mind set on two majors and two universities, as these were the best: UERJ (State University of Rio de Janeiro) and PUC (Pontifical Catholic University) and I had no interest in any other college in my life. So, I focused on those two. 
Ad: I decided to apply for PUC because I knew how famous it was. A sister of mine said to me that she worked for a law firm owned by a guy who studied at PUC and he said (...) he only accepted CVs from PUC, UFRJ (Federal University of Rio de Janeiro), and UERJ, all the others he'd throw straight into the trashcan.

The statements above indicate how these young people already 'have their mind set' on some universities that they 'know' and 'remember' as prestigious institutions. This 'mind set', 'knowing' and 'remembering' should not be regarded as a mere cognitive decision-making process by these individuals. As Bourdieu and Boltanski (1998) have noted, certain diplomas and university majors are socially valued, leading to A and Ad's identifications with a social discourse that values a university education at certain prestigious institutions entangling them within the social dynamics of social prestige and its underlying discourses.

University prestige prompts these young people to engage themselves along this path. The university hereby analyzed is shown to exert convocation due to its prestige, its academic quality. It is a place that enthralls youth, a place of excellence, as the young people referred to it during the focus groups. Therefore, they felt justified when putting their stakes on this renowned institution and made a move towards it.

In Ad's statement above, his sister was described as a privileged agent as she informed and reiterated the quality of the university. In fact, the family appeared as an important institution as it modulated and informed the educational project of all the young people in this research. As in the two excerpts below:

R: I think that my role model for continuing to study and doing all this, still my greatest example to this today, is my mother, (...) And I saw my mother's old report cards from school, and she only had high grades. So, I have to be like her, my mother didn't have many opportunities in life, but, even so, she studied...

W: My grandmother worked here at the [university], and she'd talk a lot about this place. And so, it was this process of internalizing these things. It wasn't an inner motivation in the first place, it was something people said I had to do...

These narratives underline the importance that family holds in producing identification with a university-level education. The importance of the family in the individual's subjective construction is a well-documented phenomenon in the psychoanalytic literature. Jardim and Silva Filho (1996) argue that any individual professional project is modeled within a dynamic that involves the familial other. The bourgeois nuclear family has the function of welcoming the newborn child, presenting it to the world, and inserting it within social discourses. In doing so, many parents idealize a career for their newborn child. Over time, as Jardim and Silva Filho (1996) emphasize, this individual will have to position him/herself in relation to the ideal placed by their parents, building a professional project of his/her own. A similar dynamic is at play in our case. Education, directly linked to one's professional project, emerged as an investment by the family that reminded, guided, and exerted pressure on the young people, although the individuals hereby analyzed conceived these projects as their own as they developed their own narratives about their educational choices. 
Finally, there is also a well-defined target which serves to justify the strain in the displacement from the periphery to the center: the attainment of a better place in the social hierarchy. These young people have accomplished the work demanded by the renowned university in the belief that it will eventually lead to an upward social mobility. In this regard, R said that "I want to study because it is the only way I see to change my condition". In a similar vein, W stated that "what my family has always taught me is that (...) only by studying I will have the opportunity to change my economic and financial situation and that studying would be the only way, the path to salvation."

The testimonies underscored how much their expectations about a higher education diploma from a prestigious educational institution are grounded on the belief that this may contribute to their social and economic ascension. In a highly competitive job market (Beck \& Beck-Gersheim, 2002; Boltanski \& Chiappelo, 2007; Dardot \& Laval, 2016; Sennett, 2009), a diploma from a leading educational institution emerges as an asset to acquire a good job and attain a better socioeconomic condition.

Nonetheless, this belief in upward social mobility is mingled with doubts and fears. As such, W states that "I don't know whether my project can lead anywhere, if I can plan anything in this current scenario. As I think so, I feel a kind of halt as far as planning things are concerned. So I'm afraid". In the same vein R says "I don't know, I have so many doubts at the moment. Also because of the country's situation, I don't know... it's hard to think about it."

Thus, these young people expressed doubts as to whether a good education or a university diploma are enough to secure a good job or better living conditions. Brazil is a country that has never had a well-structured labour market and the workforce has always been overexploited (Antunes, 2012), a situation that seems to further aggravate this scenario. It seems that a contradiction of the current capitalist production model paralyzes young people in the construction of their educational plans: the current labour model demands increasingly more educational training, diplomas and knowledge, while at the same time provides less job opportunities in the formal and protected labour market. While this contradiction may be found across the globe (Beck \& Beck-Gersheim, 2002 Boltanski \& Chiappelo, 2007; Dardot and Laval, 2016; Sennett, 2009), it becomes even more perverse in third world countries. Unsurprisingly, employment emerges as a topmost concern for so many young Brazilians as many of them fear being left out of the formal labour market (Guimarães, 2006). Thus, imagining a project for the future seems complicated and often impossible for young Brazilians, especially those in the lower income classes and living the periphery (Savegnano, 2018).

Nonetheless, even in a scenario of uncertainties, young people still hold some expectations for the future. Unlike the subjects studied by Savegnano (2018), the young people in our research have secured a place in a renowned university, and thus seem more inclined to mobilize their subjective resources to envision a future, even if riddled with doubt. In this regard, R reports that "I think I would be very happy if I got a job, for example, at a French multinational company, where I could speak French. That would make me happy". W tells us that "I want to set up a clinic with black psychologists only. And in that clinic, I'd want, I don't know, 50\% to be community outreach care, because I see these people in need who don't have the money to pay for these services.".

Therefore, even in a scenario marred by uncertainties, respondents idealized a future and plan to act so that it might become a reality. Such plans may have a more individualistic or a collective nature: R's desire to make money in a multinational company, preferably where she can use French, a language with which the young woman identifies; or W's plan of making enough money to build and maintain a community outreach clinic for Black people.

What we found is that family influence and the dream of social mobility are motivating factors for young people to invest in higher level education. Our findings are in tandem with other Brazilian studies with low income youth in higher education. Thus, Mongim (2015) and Piotto (2010) emphasize the importance of the family when youth consider a professional project which includes a 
higher education formation. They, as individuals, as well as their families, believe that attending this institution may lead to social mobility. The social prestige of the university in which our research took place seems to contribute to this process, as it may provide better education and qualification, and possibly secure entry into a competitive labour market.

\section{Final Thoughts}

In this article, we analyzed how young people living in the periphery of Rio de Janeiro are subjectively motivated to construct an educational trajectory towards a prestigious university in this city. We analyzed the conditions that contribute to this movement, its emerging contradictions and conflicts, and how young people have to constantly renew their expectations and hopes, adjusting their actions and plans to the difficulties they meet along the way.

We found that the prestige of the university, the family influence, and the prospect of social mobility are underlying motivators to justify the subjective commitment of young people to enroll in a high quality university institution. Nonetheless, contradictions also emerge for these individuals as they move from the periphery to occupy a place in a renowned higher education institution. The long distances from home to the university, the brusque encounter with overwhelming university demands and the segregation experienced in the institution were all mentioned by the young people as factors that demanded them to readjust their actions and expectations. And such this implies psychic labour which must be constant, at the risk of discontinuity or even abandonment of the university project and future professional aspirations.

The experience of these four participants may help us to understand part of the complex dynamic of poor young people from the peripheries who enroll in prestigious universities in Brazil. Furthermore, the converging opinions and personal accounts of the young people in our research find resonance in the national literature. This scenario reveals the limits and contradictions behind the project to integrate low-income youth from the peripheries in higher education institutions. Brazil has made tangible progress in democratizing university education by way of public policies that have enabled and promoted inclusion. While important, entry into higher education is no warranty that peripheral young people will be able to remain at this educational level. The limits of this inclusionary process become patent when analyzing abandonment in Brazilian higher education, a longstanding debate in the country, which afflicts circa $20 \%$ of students from private universities as the one analyzed (Saccaro, França \& Jacinto, 2019).

Thus, beyond a mere inclusion that public policies geared to favor the entry of low income youth in higher education allow, further investment in basic public education and actions to mitigate the country's sharp social divide are crucial. Further research addressing different university contexts are also necessary to map out different demands from young Brazilian university students and the difficulties they face.

Furthermore, our findings also expose the limits of the capitalist production system, as young people, even if enrolled in a top-level university, have no guarantees of job placement consistent with their training. Moreover, on top of educational qualification, the contemporary labour market also values other factors, such as professional contacts (Boltanski; Chiapello, 2007; Sennett, 2009), and once again the low-income youth from the peripheries find themselves at a disadvantage when compared to the middle-class youth, as the latter are more likely to have greater social capital.

Such a production model wreaks anguish upon the low-income, peripheral youth, as their arduous educational efforts may not yield the desired results. This situation is further aggravated in country such as Brazil because of its fragile labour market. We believe that alternatives to the existing social division of labour and its ensuing benefits and rewards would make the intense educational investments made by these young people less distressing and more gratifying. 


\section{References}

Almeida, W. (2007). Estudantes com desvantagens econômicas e educacionais e fruição da universidade. Cadernos $C R H, 20(49), 35-46$.

Antunes, R. (2012). A nova morfologia do trabalho no Brasil: Reestruturação e precariedade. Nueva Sociedad (Edição Especial em português), 44-59.

Associação Nacional dos Dirigentes das Instituições Federais de Ensino Superior [ANDIFES] (2018). V pesquisa nacional de perfil socioeconômico e cultural dos(as) Graduandos(as) das IFES. Universidade Federal de Uberlândia: Brasil.

Bauman, Z. (2008). A sociedade individualizada: vidas contadas e histórias vividas [The individualized society]. Zahar.

Beck, U., \& Beck-gersheim, E. (2002). Individualization: institutionalized individualism and its social and political consequences. Sage Publications.

Boltanski, L., \& Chiapello, E. (2007). The new spirit of capitalism. Verso.

Bourdieu, P. (1998). Futuro de classe e causalidade do provável. In Nogueira, M. A. \& Catani, A. (Eds.). Escritos de educação (pp. 81-126). Vozes.

Bourdieu, P., \& Boltanski, L. (1998). O diploma e o cargo: relações entre o sistema de produção e o sistema de reprodução. In Nogueira \& M. A.; Catani, A. (Eds.). Escritos de educação. (pp. 127-146) Vozes.

Cassab, M. (2001). Jovens pobres na cidade: a construção da subjetividade na desigualdade. In Castro, L. R. (Ed.). Crianças e jovens na construção da cultura (pp. 209-226). NAU/FAPERJ.

Castro, L. R. (2013). O futuro da infância e outros escritos. 7letras.

Corbucci, P. R. (2016). Desigualdades dos jovens brasileiros no acesso à educação superior. In Silva, E. R. A, \& Botelho, R. U. (Eds.). Dimensões da experiência juvenil brasileira e novos desafios às políticas públicas. (pp. 153-176). Ipea.

Cuervo, H., \& Wyn, J. (2017). A longitudinal analysis of belonging: temporal, performative and relational practices by young people in rural Australia. Young, 25(3), 219-234.

Cordeiro, A., \& Menezes, J. (2001). Fortaleza de Leste a Oeste: progresso e beleza 'pra turista ver'. Encontros com crianças e jovens em Fortaleza. In Castro, L. (Ed.) Subjetividade e cidadania: um estudo com crianças e jovens em três cidades brasileiras (pp. 21-62). 7letras.

Dardot, P., \& Laval, C. (2016). A nova razão do mundo: ensaio sobre a sociedade neoliberal. [The new way of the world: on neoliberal society] Boitempo.

Farrugia, D. (2014). Towards a spatialised youth sociology: the rural and the urban in times of change. Journal of youth studies, 17(3), 293-307.

Farrugia, D., \& Wood, B. (2017). Youth and spatiality: towards interdisciplinarity in youth studies. Young, 25(3), 209-218.

Fraser, A. Et Al. (2017). City as lens: (Re)imagining youth in Glasgow and in Hong Kong. Young, 25(3), 235-251.

Geldens, P., \& Bourke, L. (2008). Identity, uncertainty and responsibility: privileging place in a risk society. Children's Geographies, 6(3), 281-294.

Gieryn, T. (2000). A space for place in sociology. Annual Review of Sociology, 26, 463-496.

Jensen, M. (2006). Mobility among young urban dwellers. Young, 14(4), 343-361.

Lahire, B. (1997). Sucesso escolar nos meios populares: as razões do improvável. [Tableaux de familles - Heus et malheus scholaires en milieux populaire]. Ática

Lebourg, E., \& Coutrin, R. (2018). Eu não queria estar aqui: juventude, ensino médio e deslocamento. Educação \& Realidade, 43(2), 609-627. 
Mayorga, C., Costa, F., \& Cardoso, T. (2010). Universidade pública no Brasil: entre direitos e privilégios. In Mayorga, C. (Ed.). Universidade cindida, universidade em conexão: ensaios sobre a democratização da universidade. (pp. 19-45). UFMG.

Mayorga, C. Costa-Moura, F., \& Savegnago, S. (2019). Sintomas do mal-estar na universidade brasileira: onde estamos e para onde vamos? DESIDADES, 24, 42-58.

Mongim, A. (2015). Crescimento pessoal, mediação e sacrifício: itinerários sociais de estudantes beneficiários do ProUni. Educação \& Sociedade, 26(133), 927-943.

Neves, C. E. B, \& Martins, C. B. (2016). Ensino superior no Brasil: uma visão abrangente. In Dwyer, T. ET AL. Jovens universitários em um mundo em transformação: uma pesquisa sinobrasileira (pp. 95-124). IPEA.

Peregrino, M.; \& Fernandez, A. (2014). O território como variável-chave na transição para a vida adulta: o caso de jovens matriculados no programa Projovem Trabalhador do município de São Gonçalo. (pp. 66-75). In Andrade, E., Pinheiro, D., \& Esteves, L. (Eds.) Juventude em perspectiva: múltiplos enfoques. UNIRIO/PROExC.

Pérez, B., \& Castro, L. (2011). Jovens no Rio de Janeiro: percursos, inseguranças e riscos. Educação, $36(1), 107-120$.

Piotto, D. (2010). Universitários de camadas populares em cursos de alta seletividade: aspectos subjetivos. Revista Brasileira de Orientação Profissional, 11(2), 229-242.

Santos, M. (2001). Por uma outra globalização: do pensamento único à consciência universal. [Toward an other globalization: from the single thought to universal conscience.] Record.

Savegnago, S. (2018). Oportunidades de vida: fortuidades do tempo e mobilidades no espaço de jovens pobres cariocas. (Doctoral Dissertation). Retrieved from Minerva, UFRJ Database (http://objdig.ufrj.br/30/teses/870977.pdf).

Schlemmler, B. (2005). Quando a escola é uma opção - relação com a escola e relação com os saberes em Marrocos. Análise Social, 40(176), 547-562.

Sennett, R. (2009). A corrosão do caráter: as consequências pessoais do trabalho no novo capitalismo. [The corrosion of character: the personal consequences of work in the new capitalism] Record.

Stahl, G. \& Baars, S. (2016). How "space" and "place" contribute to occupational aspirations as a value-constituting practice for working-class males. Education + Training, 58(3), 313-327.

Stahl, G.; Habib, S. (2017). Moving beyond the confines of the local: working-class students' conceptualizations of belonging and respectability. Young, 25(3), 268-285.

Vasconcelos, A. M. N. (2016). Juventude e ensino superior no Brasil. In Dwyer, T. ET AL. Jovens universitários em um mundo em transformação: uma pesquisa sino-brasileira. (pp. 125-138). IPEA.

Waqcquant, L. (2007). Esclarecer o habitus. Educação e Linguagem, 16, 63-71.

Weisheimer, N. (2013). Sobre a invisibilidade social das juventudes rurais. DESIDADES, 1, 22-27.

Zago, N. (2006). Do acesso a permanência no ensino superior: percurso de estudantes universitários de classes populares. Revista Brasileira de Educação, 11(32), 226-237. 